\title{
Utilization of Coal Fly Ash and Oil Palm Empty Fruit Bunch Compost to Improve the Uptake of Soil Phosphorus and Yield of Maize Grown on Ultisol
}

\author{
Fahrunsyah', Zaenal Kusuma², Budi Prasetya², Eko Handayanto ${ }^{3 *}$ \\ 1 Department of Agroecotechnology, Faculty of Agriculture, Mulawarman University, Jl. Paser Belengkong, \\ Samarinda, East Kalimantan, Indonesia \\ 2 Department of Soil Science, Faculty of Agriculture, Brawijaya University, Jl. Veteran, Malang, East Java 65145, \\ Indonesia \\ ${ }^{3}$ Research Centre for the Management of Degraded and Mining Lands, Brawijaya University, Jl. Veteran, \\ Malang, East Java 65145, Indonesia \\ * Corresponding author's e-mail: handayanto@ub.ac.id
}

\begin{abstract}
The study aimed at elucidating the utilization of coal fly ash and oil palm empty fruit bunch compost to improve the soil phosphorus uptake and yield of maize grown on Ultisol. The investigation was carried out in a greenhouse. The treatments tested were a combination of four coal fly ash doses $\left(0,20,40\right.$, and $\left.80 \mathrm{tha}^{-1}\right)$ and three doses of oil palm empty fruit bunch compost $\left(0,10\right.$, and $\left.20 \mathrm{t} \mathrm{ha}^{-1}\right)$. At 2, 4, 6 and 8 weeks after planting, plant height, leaf number and stem diameter were observed. At the time of harvest (10 weeks after planting), fresh and dry weights of cobs, roots, stem, leaves, and seeds, as well as P uptake on the plant tissues, were observed. The results showed that the application of coal fly ash and oil palm empty fruit bunch compost significantly increased the P uptake, growth and yield of maize. The combination of $80 \mathrm{t}$ coal fly ash ha ${ }^{-1}$ with $20 \mathrm{t}$ oil palm empty fruit bunch compost $\mathrm{ha}^{-1}$ resulted in the highest $\mathrm{P}$ uptake, growth and yield of maize. Compared to the control treatment, the increase in P uptake by maize, the fresh cob weight, the dry cob weight, the biomass dry weight, and the dry seed weight were $303.23 \%, 285.39 \%, 364.91 \%, 329.59 \%$ and $1,591.70 \%$, respectively.
\end{abstract}

Keywords: coal fly ash; maize; oil palm empty fruit bunch compost; P uptake; Ultisol

\section{INTRODUCTION}

In Indonesia, Ultisols are commonly found in Sumatra, Kalimantan, Sulawesi and Papua with an area of up to 45.8 million hectares or around $25 \%$ of the land area of Indonesia (Sudaryono, 2009). One of the problems of Ultisols utilization for agriculture is the low availability of phosphorus $(\mathrm{P})$ to support the optimal plant growth. The availability of $\mathrm{P}$ in Ultisols is around 3.4-19 ppm (Hilman et al., 2007). Therefore, phosphorus is one of the elements that limit the growth of plants in Ultisols (Shenoy and Kalagudi, 2005). The low availability of $\mathrm{P}$ is due to the strong binding of $\mathrm{P}$ by $\mathrm{Al}$ and $\mathrm{Fe}$ so that it is not available for plants (Thao et al., 2008). The P element plays a vital role in photosynthesis, respiration, physiological and biochemical regulation of plants and acts as energy storage in the plant metabolism of through ADP transformation to ATP (Shen et al., 2011). If the plant is deficient in P, the RNA synthesis decreases so that the protein synthesis process is hindered and results in stunted plant growth, and inhibited fruit ripening (Mengel et al., 2001). A previous study conducted by Fahrunsyah et al. (2018) showed that the application of coal fly ash combined with oil palm empty fruit bunch compost increased the availability of $\mathrm{P}$ in an Ultisol of East Kalimantan. The best combination of coal fly ash and oil palm empty fruit bunch compost was $80 \mathrm{t}$ coal fly ash ha $\mathrm{a}^{-1}$ and $20 \mathrm{t}$ oil palm empty fruit bunch compost ha ${ }^{-1}$, which could increase the $\mathrm{P}$ available to soil by $542 \%$. However, the effects of increasing the availability of $\mathrm{P}$ in the Ultisol on 
the improvement of $\mathrm{P}$ uptake, growth and yield of food crops have not been studied.

In Indonesia, coal fly ash, which is a coalburning waste in Steam Power Plant and other industries that use coal as fuel, amounted to 4 million tons in 2012 (Hermawan et al., 2014). ASTM (1998) defined coal fly ash as a fine grain of coal combustion residues. The ash is a mixture of particles with very complex compositions (Kurniawan et al., 2010). Because of the high concentration of various elements in the coal fly ash, many studies have evaluated the usefulness of coal fly ash in soils that lack nutrients (Kishor et al., 2010; Singh et al., 2010). Coal fly ash can be used as a source of $\mathrm{B}, \mathrm{Ca}, \mathrm{Cu}, \mathrm{K}, \mathrm{Mg}$, Mo, $\mathrm{S}$ and $\mathrm{Zn}$ (Singh et al., 2010). If coal fly ash is used to improve the acid soil fertility, it mainly increases the availability of micronutrients, copper, zinc and manganese to enhance the plant growth (Spark et al., 2008). Although the benefits of using coal fly ash for agriculture are still debated because of the heavy metals content in the coal fly ash (Lee et al., 2006; Sharma and Kalra, 2006; Mahale et al., 2012; Ukwattage et al., 2013), several research results showed that the coal fly ash application in acid soils could increase the growth and yield of wheat and sorghum (Sharma and Kalra, 2006; Aggarwal et al., 2009; Mahale et al., 2012), maize (Sharma and Kalra, 2006), and tomato (Ismail et al., 2017). In sunflower plants, heavy metals $(\mathrm{Cd}, \mathrm{Cu}$ and $\mathrm{Zn})$ from coal fly ash did not have a significant effect on the dry weight of plants, but provided good growth in the stems, leaves and roots (Chaves et al., 2011).

Oil palm empty fruit bunch is a solid waste of oil palm processing which is commonly found in East Kalimantan. Mohammad et al. (2012) reported that most oil palm empty fruit bunch was returned to oil palm plantations, both in fresh form and as compost (Budianta et al., 2010). Studies have shown that oil palm empty fruit bunch can be used as an organic fertilizer to improve soil fertility (Udoetok, 2012). Application of oil palm empty fruit bunch compost could increase the yield of soybean by $50 \%$ (Budianta et al., 2010; Ermadani and Muzar, 2011). Ismail et al. (2017) reported that applying oil palm empty fruit bunch compost increased plant height, leaf area, dry matter accumulation, and suppressed the development of bacterial wilt disease on tomato, compared to using chicken manure. Bakar et al. (2015) reported that the application of oil palm empty fruit bunch biochar combined with organic fertilization and intermittent irrigation has the potential to improve the rice yield on acid sulphate soil. The increase in crop yields is also related to the improvements in soil chemical properties, including the $\mathrm{P}$ available due to an application of oil palm empty fruit bunch compost (Ichriani et al., 2017). This study aimed at exploring the utilization of coal fly ash and oil palm empty fruit bunch compost to improve the soil phosphorus uptake and yield of maize grown on Ultisol of East Kalimantan.

\section{MATERIALS AND METHODS}

This study was carried out in a greenhouse at Mangkurawang Village. Tenggarong Sub district, Kutai Kartanegara Regency, East Kalimantan Province, from February to June 2018. The soil used as planting media in this study was Ultisol taken from the study area. The characteristics of the Ultisol topsoil $(0-20 \mathrm{~cm})$ were as follows: clay texture ( $25 \%$ sand, $49 \%$ silt, $26 \%$ clay), water available content $13.87 \%, \mathrm{pH}\left(\mathrm{H}_{2} \mathrm{O}\right) 4.1$, organicC $1.23 \%$, total N $0.14 \%$, total P 37.22 ppm, available P 3.76 ppm, exchangeable cations of $\mathrm{Ca}, \mathrm{Mg}$, $\mathrm{K}, \mathrm{Na}, \mathrm{Al}$ and $\mathrm{H}-3.17,1.08,0.12,0.13,4.45$, and $1.08 \mathrm{cmol} \mathrm{kg}^{-1}$, respectively, cation exchange capacity $21.18 \mathrm{cmol} \mathrm{kg}^{-1}$, and base saturation $44.87 \%$ (Fahrunsyah et al., 2018). Coal fly ash was obtained from the Steam Power Plant of PT. Cahaya Fajar Kaltim at Embalut Village, Tenggarong Seberang Sub district, Kutai Kartanegara Regency, East Kalimantan Province. The characteristics of coal fly ash were as follows: silt texture ( $9 \%$ sand, $90 \%$ silt, $1 \%$ clay), water available content $18.86 \%, \mathrm{pH}\left(\mathrm{H}_{2} \mathrm{O}\right) 9.8$, organic-C $0.82 \%$, total-N $0.05 \%$, total-P 1.378 ppm, available $\mathrm{P}$ 5.73 ppm, total K 719.35 ppm, exchangeable cations of $\mathrm{Ca}, \mathrm{Mg}, \mathrm{K}, \mathrm{Na}$, and $\mathrm{H}-28.45,3.25,0.25$, 0.26 , and $0.08 \mathrm{cmol} \mathrm{kg}^{-1}$, respectively, cation exchange capacity $17.37 \mathrm{cmol} \mathrm{kg}^{-1}$, and base saturation $99.75 \%$ (Fahrunsyah et al., 2018). Oil palm empty fruit bunch compost was obtained from PT. Surya Inti Sawit Kahuripan (Makin Group), Parenggean District, Kotawaringin Timur, Central Kalimantan Province. In turn, the characteristics of the oil palm empty fruit bunch were the following: $\mathrm{pH}\left(\mathrm{H}_{2} \mathrm{O}\right) 6.7$, organic-C $17.30 \%$, total $\mathrm{N} 1.56 \%$, total P 3,700 ppm, total K 1,100 ppm, exchangeable cations of $\mathrm{Ca}, \mathrm{Mg}, \mathrm{K}$, and $\mathrm{Na}-$ $3.49,1.21,0.52$, and $0.82 \mathrm{cmol} \mathrm{kg}^{-1}$, respectively (Fahrunsyah et al., 2018). 
Each treatment combination of four coal fly ash (A) doses (0, 20, 40 and $\left.80 \mathrm{tha}^{-1}\right)$ and three doses of oil palm empty fruit bunch compost $(\mathrm{K})$ $\left(0,10\right.$, and $\left.20 \mathrm{tha}^{-1}\right)$ was mixed with $15 \mathrm{~kg}$ of airdried topsoil that passed through a $2 \mathrm{~mm}$ sieve, in a plastic pot having a diameter of $35 \mathrm{~cm}$ and a height of $25 \mathrm{~cm}$. The mixtures of coal fly ash, oil palm empty fruit bunch compost, and soil in the pots were then incubated for 15 days. During incubation, the soil moisture in each pot was maintained at $80 \%$ of the soil water holding capacity. The twelve treatments were arranged in a completely randomized design with three replicates. After incubation (15 days), all pots received basal fertilizers consisting of $31 \mathrm{mg} \mathrm{N} \mathrm{kg}^{-1}(150 \mathrm{~kg}$ Urea ha $\left.{ }^{-1}\right)$ and $20 \mathrm{mg} \mathrm{K}_{2} \mathrm{O} \mathrm{kg}^{-1}\left(75 \mathrm{~kg} \mathrm{KCl} \mathrm{ha}^{-1}\right)$. The moisture content of each pot was adjusted to its approximate water holding capacity. Two pregerminated seeds of maize (Bonanza F1 variety) were planted in each pot and thinned to one plant after one week. Water was supplied daily to each pot to keep the moisture content of the soil at the approximate water holding capacity. At 35 days after planting, the second application of $\mathrm{N}$ fertilizer was made to all pots with a dose of $31 \mathrm{mg} \mathrm{N}$ $\mathrm{kg}^{-1}\left(150 \mathrm{~kg} \mathrm{Urea} \mathrm{ha}^{-1}\right)$. At 2, 4, 6, and 8 weeks after planting, observations were made on the plant height, number of leaves, and stem diameter of maize plants. At the time of harvest ( 10 weeks after planting), fresh and dry weights of cobs, roots, stem, leaves, and seeds, as well as the P uptake on the plant tissues, were observed. The plant materials were oven dried at $60^{\circ} \mathrm{C}$ for 48 hours. The content of $\mathrm{P}$ in the roots, stems, leaves, and seeds was measured using the west ash method employing $\mathrm{HNO}_{3}$ and $\mathrm{HClO}_{4}$ (Soil Research Institute of Indonesia, 2005). The uptake of $\mathrm{P}$ by plant tissue is the content of $\mathrm{P}(\%)$ multiplied by the dry weight of plant tissue. The data obtained were subjected to analysis of variance followed by the Duncan Multiple Range Test (DMRT) at 5\% level.

\section{RESULTS AND DISCUSSION}

\section{$\mathrm{P}$ uptake by maize}

The application of coal fly ash and oil palm empty fruit bunch compost significantly increased the P uptake by maize (Table 1). The P uptake by maize increased along with the doses of coal fly ash applied. The lowest $\mathrm{P}$ uptake by maize (71.68 mg plant ${ }^{-1}$ ) was found in the control treatment. The low P uptake in the control treatment was probably due to the low available $\mathrm{P}$ content (3.76 ppm) of the soil used in this study. According to Minardi et al. (2017), the uptake of $\mathrm{P}$ by plants is largely determined by the concentration of $\mathrm{P}$ in the soil and the ability of plants to absorb the $\mathrm{P}$ in the soil. The highest $\mathrm{P}$ uptake by maize (289.76 mg plant $^{-1}$ ) was obtained in the A80K20 treatment which was not significantly different from the A $80 \mathrm{~K} 10$ treatment, but it was significantly different from other treatments. When compared with the P uptake by maize in the control treatment, the A80K20 treatment increased the P uptake by

Table 1. Effect of coal fly ash and oil palm empty fruit bunch compost on the P uptake by maize

\begin{tabular}{|c|c|c|c|c|c|c|c|c|c|c|c|c|}
\hline \multirow{3}{*}{$\begin{array}{c}\text { Treatments } \\
\text { AOKO }\end{array}$} & \multicolumn{12}{|c|}{ Uptake of $\mathrm{P}\left(\mathrm{mg} \mathrm{plant}^{-1}\right)$} \\
\hline & \multicolumn{2}{|c|}{ Root } & \multicolumn{2}{|c|}{ Stem } & \multicolumn{2}{|c|}{ Leaf } & \multicolumn{2}{|c|}{ Seed } & \multicolumn{2}{|c|}{ Cob } & \multicolumn{2}{|c|}{ Total } \\
\hline & 9.16 & $d$ & 16.37 & $d$ & 26.92 & $\mathrm{e}$ & 8.56 & $\mathrm{~h}$ & 10.83 & $\mathrm{e}$ & 71.84 & $\mathrm{~h}$ \\
\hline $\mathrm{A} 20 \mathrm{KO}$ & 10.02 & $\mathrm{~cd}$ & 31.96 & c & 50.53 & $d$ & 33.90 & $g$ & 12.24 & de & 138.61 & g \\
\hline $\mathrm{A} 40 \mathrm{KO}$ & 10.97 & abcd & 35.39 & c & 54.75 & $c d$ & 48.70 & ef & 19.82 & cde & 169.63 & efg \\
\hline A80K0 & 12.07 & abcd & 37.76 & $\mathrm{bc}$ & 68.51 & bcd & 75.97 & $\mathrm{bc}$ & 35.41 & a & 229.72 & $\mathrm{~cd}$ \\
\hline A0K10 & 10.57 & bc & 31.74 & c & 50.24 & $d$ & 31.81 & $g$ & 14.95 & cde & 139.31 & g \\
\hline A0K20 & 10.45 & bcd & 32.83 & c & 54.24 & $c d$ & 35.32 & $\mathrm{fg}$ & 21.71 & bcd & 154.55 & $\mathrm{fg}$ \\
\hline $\mathrm{A} 20 \mathrm{~K} 10$ & 12.09 & abcd & 33.70 & $\mathrm{c}$ & 62.92 & $\mathrm{~cd}$ & 55.82 & de & 19.96 & cde & 184.49 & ef \\
\hline A20K20 & 13.19 & $a b c$ & 34.09 & c & 65.64 & $c d$ & 66.66 & $\mathrm{~cd}$ & 23.92 & bc & 203.50 & de \\
\hline A40K10 & 13.46 & $a b c$ & 47.60 & $a b c$ & 68.24 & bcd & 67.56 & $\mathrm{~cd}$ & 24.92 & bc & 221.78 & $\mathrm{~cd}$ \\
\hline A40K20 & 13.97 & $a b$ & 51.02 & $a b$ & 72.26 & $a b c$ & 74.20 & $\mathrm{bc}$ & 31.42 & $a b$ & 242.87 & $\mathrm{bc}$ \\
\hline A80K10 & 14.54 & a & 53.71 & $a$ & 84.84 & $a b$ & 82.72 & $a b$ & 35.91 & a & 271.72 & $a b$ \\
\hline A80K20 & 14.80 & a & 55.47 & a & 88.63 & a & 92.44 & $a$ & 38.42 & a & 289.76 & a \\
\hline
\end{tabular}

Remarks: $A=$ coal fly ash; $K=$ oil palm empty fruit bunch compost; $0,10,20.40$ and $80=$ Doses of coal fly ash or oil palm empty fruit bunch compost. Numbers followed by the same letter in the same column are not significantly different at $\alpha$ 5\% DMRT. 
$303.23 \%$. The data presented in Table 1 show that the application of coal fly ash without oil palm empty fruit bunch compost resulted in an increase of the P uptake in the A20K0, A40K0, and A80K0 treatments by $92.94 \%, 136.11 \%$, and $219.68 \%$, respectively, compared to the control. The ability of coal fly ash in enhancing the P uptake by maize was due to an increase in the availability of soil $\mathrm{P}$, both from the original $\mathrm{P}$ of the soil (through an increase in $\mathrm{pH}$ ) and the $\mathrm{P}$ derived from coal fly ash (Fahrunsyah et al., 2018).

As coal fly ash, the application of oil palm empty fruit bunch compost without coal fly ash also increased $\mathrm{P}$ uptake by maize, and the increase was in line with the increasing doses of oil palm empty fruit bunch compost. The P uptake was raised by $93.81 \%$ in the A0K 10 treatment and $115.93 \%$ in the A20K0 treatment compared to the control treatment (Table 1). The ability of oil palm empty fruit bunch compost to increase the $\mathrm{P}$ uptake by maize seemed to be related to the decomposition process of oil palm empty fruit bunch compost in the soil. The decomposition of oil palm empty fruit bunch compost produces organic acids such as humic acid, fulvic acid, lactic acid, acetic acid and oxalic acid which can bind metals such as $\mathrm{Al}, \mathrm{Fe}$ and $\mathrm{Mn}$, thus reducing the activity of the metal in absorbing $\mathrm{P}$ and increasing the $\mathrm{P}$ availability to soil (Haynes and Mokolobate, 2001; Ifansyah, 2013). Another mechanism for increasing the $\mathrm{P}$ availability is that oil palm empty fruit bunch compost had a high total $\mathrm{P}$ content (3,700 ppm). Fahrunsyah et al. (2018) reported that application of oil palm empty fruit bunch compost with doses of $10 \mathrm{tha}^{-1}$ and $20 \mathrm{t} \mathrm{ha}^{-1}$ increased the soil $\mathrm{P}$ availability by $80.90 \%$ and $158.79 \%$, respectively. Budianta et al. (2010) reported that the application of oil palm empty fruit bunch compost at a dose of $21 \mathrm{tha}^{-1}$ increased the $\mathrm{P}$ availability by $73.8 \%$ and increased the $\mathrm{P}$ uptake by soybean by $198 \%$, compared to control. The ability of plants to take up P is determined by the availability of $\mathrm{P}$ in the soil; soil having high $\mathrm{P}$ availability has the potential to produce greater P uptake by plants (Balemi and Negisho, 2012). The application of $80 \mathrm{t}$ coal fly ash ha ${ }^{-1}$ and $20 \mathrm{t}$ oil palm empty fruit bunch compost ha-1 (A80K20 treatment) resulted in the $\mathrm{P}$ uptake by maize of $289.76 \mathrm{mg} \mathrm{plant}^{-1}$. Compared with the $\mathrm{P}$ uptake in the A80K0 treatment ( $80 \mathrm{t}$ coal fly ash $\mathrm{ha}^{-1}$ ) and the A0K20 treatment (20 t oil palm empty fruit bunch compost ha ${ }^{-1}$ ), the A80K20 treatment increased the P uptake by $26.14 \%$ and $86.74 \%$, respectively. The results of a previous study reported by Fahrunsyah et al. (2018) showed that the combination of coal fly ash and oil palm empty fruit bunch compost was able to increase the availability of soil P to a greater extent than coal fly ash or oil palm empty fruit bunch compost alone. Ashish (2017) reported that the combined application of coal fly ash and chemical fertilizer with either farmyard manure or compost helped in improving the measured growth parameters, as compared to coal fly ash alone and control.

Overall (12 treatments), the amounts of $\mathrm{P}$ taken up by roots, stems, seeds, and cobs were $6.31 \%, 19.89 \%, 32.25 \%$, and $29.07 \%$, respectively. This shows that most of the P taken up by plants was in leaves and seeds. However, when observed between treatments, there was a tendency for maize that most of the P uptake was observed in the seeds and the least P uptake was in the roots (Table 1). For example, the A80K20 treatment produced the highest $\mathrm{P}$ uptake $(31.90 \%)$ in the seeds, and the least P uptake (5.11\%) was observed in the root. If $\mathrm{P}$ was taken up slightly, for example in the control treatment, most of the P taken up $(37.50 \%)$ was by the leaves, and the least $(11.50 \%)$ was found in the seeds. This caused the control treatment produce smaller cobs and seeds than other treatments.

\section{Growth of maize}

The application of coal fly ash and oil palm empty fruit bunch compost did not significantly affect the plant height, stem diameter and number of leaves at 2 weeks after planting (Tables 2, 3, and 4). However, at the age of 4 and 6 weeks after planting, the application of coal fly ash and oil palm empty fruit bunch compost did significantly affect the plant height, stem diameter and leaves. The control treatment produced the lowest growth that was significantly different from other treatments. The A80K20 treatment produced the highest plant growth. This is related to the increased availability of $\mathrm{P}$ in the soil due to coal fly ash and oil palm empty fruit bunch compost (Fahrunsyah et al., 2018), which in turn increased the P uptake by maize. The supply of nutrients which are conducive to the physical environment leads to better aeration, the activity of roots and absorption of nutrients and complementary effects due to fly ash applications with organic and inorganic fertilizers will result in higher grain and straw yields (Reddy et al. (2010). Panda et al. (2015) reported 
Table 2. Effect of coal fly ash and oil palm empty fruit bunch compost on the height of maize plant

\begin{tabular}{|c|c|c|c|c|c|c|c|c|}
\hline \multirow{3}{*}{$\begin{array}{c}\text { Treatments } \\
\text { AOKO }\end{array}$} & \multicolumn{8}{|c|}{ Plant height $(\mathrm{cm})$} \\
\hline & \multicolumn{2}{|c|}{2 WAP } & \multicolumn{2}{|c|}{4 WAP } & \multicolumn{2}{|c|}{6 WAP } & \multicolumn{2}{|c|}{8 WAP } \\
\hline & 30.27 & $a$ & 53.02 & $\mathrm{e}$ & 71.95 & $\mathrm{e}$ & 126.37 & $\mathrm{e}$ \\
\hline A20K0 & 35.43 & a & 86.68 & $d$ & 118.67 & $\mathrm{~cd}$ & 222.27 & c \\
\hline $\mathrm{A} 40 \mathrm{~K} 0$ & 32.30 & $a$ & 89.33 & $\mathrm{~cd}$ & 124.60 & $\mathrm{bc}$ & 233.45 & $\mathrm{bc}$ \\
\hline $\mathrm{A} 80 \mathrm{~K} 0$ & 33.87 & $a$ & 96.47 & $a b c$ & 144.40 & $a b$ & 252.48 & $a b$ \\
\hline A0K10 & 36.78 & $a$ & 88.85 & $\mathrm{~cd}$ & 103.07 & $\mathrm{~d}$ & 178.40 & $d$ \\
\hline A0K20 & 33.53 & $a$ & 93.55 & bcd & 125.53 & $\mathrm{bc}$ & 232.33 & $\mathrm{bc}$ \\
\hline A20K10 & 35.68 & $a$ & 99.70 & $a b$ & 146.83 & $\mathrm{a}$ & 242.38 & $a b c$ \\
\hline A20K20 & 37.27 & $a$ & 104.82 & $\mathrm{a}$ & 160.67 & $a$ & 245.15 & $a b$ \\
\hline A40K10 & 34.60 & a & 104.82 & $a$ & 163.43 & $a$ & 259.02 & $\mathrm{a}$ \\
\hline A40K20 & 33.77 & $a$ & 105.42 & $a$ & 165.90 & $a$ & 262.35 & $a$ \\
\hline A80K10 & 36.92 & $a$ & 105.00 & $\mathrm{a}$ & 164.40 & $a$ & 261.23 & $\mathrm{a}$ \\
\hline A80K20 & 34.03 & a & 106.13 & $a$ & 166.18 & $a$ & 262.98 & $a$ \\
\hline
\end{tabular}

Remarks: $A$ = coal fly ash; $K=$ oil palm empty fruit bunch compost; 0, 10, 20. 40 and $80=$ Doses of coal fly ash or oil palm empty fruit bunch compost. WAP = weeks after planting. Numbers followed by the same letter in the same column are not significantly different at $\alpha$ 5\% DMRT.

Table 3. Effect of coal fly ash and oil palm empty fruit bunch compost on the stem diameter of maize plant

\begin{tabular}{|c|c|c|c|c|c|c|c|c|}
\hline \multirow{3}{*}{$\frac{\text { Treatments }}{\mathrm{AOKO}}$} & \multicolumn{8}{|c|}{ Stem diameter $(\mathrm{mm})$} \\
\hline & \multicolumn{2}{|c|}{2 WAP } & \multicolumn{2}{|c|}{4 WAP } & \multicolumn{2}{|c|}{6 WAP } & \multicolumn{2}{|c|}{8 WAP } \\
\hline & 6.27 & $\mathrm{a}$ & 8.17 & $\mathrm{c}$ & 9.83 & $f$ & 12.17 & $\mathrm{e}$ \\
\hline $\mathrm{A} 20 \mathrm{KO}$ & 7.30 & $\mathrm{a}$ & 11.33 & $\mathrm{~b}$ & 15.33 & de & 21.83 & $\mathrm{~cd}$ \\
\hline A40K0 & 6.37 & $\mathrm{a}$ & 11.67 & $\mathrm{~b}$ & 16.00 & $\mathrm{bcd}$ & 23.00 & $\mathrm{bc}$ \\
\hline A80K0 & 7.17 & $\mathrm{a}$ & 12.67 & $a b$ & 16.67 & bcd & 23.50 & $a b c$ \\
\hline A0K10 & 6.67 & $\mathrm{a}$ & 11.33 & $b$ & 13.50 & e & 20.67 & d \\
\hline A0K20 & 6.60 & $\mathrm{a}$ & 11.83 & $\mathrm{~b}$ & 15.33 & de & 23.17 & $a b c$ \\
\hline $\mathrm{A} 20 \mathrm{~K} 10$ & 6.87 & $\mathrm{a}$ & 13.17 & $a b$ & 15.50 & cde & 24.33 & $a b$ \\
\hline A20K20 & 7.77 & $\mathrm{a}$ & 14.67 & $\mathrm{a}$ & 16.67 & $\mathrm{bcd}$ & 24.50 & $a b$ \\
\hline $\mathrm{A} 40 \mathrm{~K} 10$ & 7.20 & $\mathrm{a}$ & 14.50 & $\mathrm{a}$ & 17.50 & $a b c$ & 24.67 & $a b$ \\
\hline $\mathrm{A} 40 \mathrm{~K} 20$ & 7.23 & $\mathrm{a}$ & 14.83 & a & 18.83 & a & 25.33 & $a b$ \\
\hline A80K10 & 7.13 & $\mathrm{a}$ & 14.67 & $a$ & 18.00 & $a b$ & 25.33 & $a b$ \\
\hline A80K20 & 7.17 & $a$ & 14.83 & $a$ & 19.00 & $a$ & 25.67 & C \\
\hline
\end{tabular}

Remarks: $\mathrm{A}=$ coal fly ash; $\mathrm{K}=$ oil palm empty fruit bunch compost; 0, 10, 20. 40 and $80=$ Doses of coal fly ash or oil palm empty fruit bunch compost. WAP = weeks after planting. Numbers followed by the same letter in the same column are not significantly different at $\alpha$ 5\% DMRT.

Table 4. Effect of coal fly ash and oil palm empty fruit bunch compost on the number of leaves of maize plant

\begin{tabular}{|c|c|c|c|c|c|c|c|c|}
\hline \multirow{2}{*}{ Treatments } & \multicolumn{9}{|c|}{ Number of leaves (sheet) } \\
\cline { 2 - 10 } & \multicolumn{2}{|c|}{ 2 WAP } & \multicolumn{2}{|c|}{4 WAP } & \multicolumn{2}{c|}{6 WAP } & \multicolumn{2}{c|}{8 WAP } \\
\hline A0KO & 4.50 & $\mathrm{a}$ & 7.33 & $\mathrm{f}$ & 8.33 & $\mathrm{~d}$ & 11.50 & $\mathrm{~d}$ \\
\hline A2OK0 & 5.00 & $\mathrm{a}$ & 9.17 & $\mathrm{cde}$ & 13.33 & $\mathrm{~b}$ & 16.17 & $\mathrm{~b}$ \\
\hline A40K0 & 4.83 & $\mathrm{a}$ & 9.33 & $\mathrm{~cd}$ & 13.50 & $\mathrm{~b}$ & 16.67 & $\mathrm{ab}$ \\
\hline A80K0 & 4.83 & $\mathrm{a}$ & 9.50 & $\mathrm{bcd}$ & 14.50 & $\mathrm{ab}$ & 18.00 & $\mathrm{a}$ \\
\hline A0K10 & 5.00 & $\mathrm{a}$ & 8.33 & $\mathrm{e}$ & 11.67 & $\mathrm{c}$ & 13.50 & $\mathrm{c}$ \\
\hline A0K20 & 4.83 & $\mathrm{a}$ & 8.83 & $\mathrm{de}$ & 13.00 & $\mathrm{bc}$ & 16.67 & $\mathrm{ab}$ \\
\hline A20K10 & 5.00 & $\mathrm{a}$ & 10.00 & $\mathrm{abc}$ & 14.00 & $\mathrm{ab}$ & 17.33 & $\mathrm{ab}$ \\
\hline A20K20 & 5.00 & $\mathrm{a}$ & 10.33 & $\mathrm{ab}$ & 14.17 & $\mathrm{ab}$ & 17.50 & $\mathrm{ab}$ \\
\hline A40K10 & 4.83 & $\mathrm{a}$ & 10.33 & $\mathrm{ab}$ & 14.50 & $\mathrm{ab}$ & 17.67 & $\mathrm{ab}$ \\
\hline A40K20 & 4.83 & $\mathrm{a}$ & 10.50 & $\mathrm{a}$ & 14.67 & $\mathrm{ab}$ & 18.17 & $\mathrm{a}$ \\
\hline A80K10 & 5.00 & $\mathrm{a}$ & 10.33 & $\mathrm{ab}$ & 15.33 & $\mathrm{a}$ & 18.50 & $\mathrm{a}$ \\
\hline A80K20 & 5.00 & $\mathrm{a}$ & 10.67 & $\mathrm{a}$ & 15.33 & $\mathrm{a}$ & 18.50 & $\mathrm{a}$ \\
\hline
\end{tabular}

Remarks: $A$ = coal fly ash; $K=$ oil palm empty fruit bunch compost; $0,10,20.40$ and $80=$ Doses of coal fly ash or oil palm empty fruit bunch compost. WAP = weeks after planting. Numbers followed by the same letter in the same column are not significantly different at $\alpha$ 5\% DMRT. 
that $40 \%$ of fly ash level was beneficial for plant growth. The response of plants to coal fly ash was also reported by other researchers, such as Bharti et al. (2000), on green grams, and Pathan et al. (2003), on Cynodon dactylon. Their findings indicate that the concentration of fly ash for improving plant growth varies from plant to plant. Muduli et al. (2014) reported the stimulating effect of fly ash on various growth parameters like length, fresh and dry weight of roots and shoots, germination rate and chlorophyll content of leguminous crops.

\section{Yield components of maize}

The application of coal fly ash and oil palm empty fruit bunch compost significantly affected the dry weight of plant biomass (cobs, root, stems, leaves, and seeds) (Table 5). The highest dry weight of plant biomass, obtained in the A $80 \mathrm{~K} 20$ treatment, increased by $329.59 \%$ compared to the control treatment. In addition, the dry weight of seeds in the A80K20 treatment was almost four times greater than that in the control treatment. The dry weight of seeds produced in the A $80 \mathrm{~K} 20$ treatment increased by $1,591.70 \%$ compared to the control treatment. However, the effect of the treatment on dry seed weight was not significantly different from the A20K20, A40K10, A40K20, and $\mathrm{A} 80 \mathrm{~K} 10$ treatments. The application of materials generated from oil palm empty fruit bunch (biochar, compost, and phosphate solubilizing fungi) on Ultisol of Kalimantan significantly improved the growth and yield of maize, as well as its the phosphorus uptake and uptake efficiency (Ichriani et al., 2018). Ekpo et al. (2014) revealed that oil palm empty fruit bunches amendments were able to ameliorate the effect of the crude oil pollution as well as enhance the germination and growth performance of the white mangrove ( $\mathrm{La}$ guncularia racemosa) species.

\section{CONCLUSION}

The application of coal fly ash and oil palm empty fruit bunch compost on Ultisol of East Kalimantan resulted in significantly higher P uptake and better growth and yield of maize plant than the application of coal fly ash or oil palm empty fruit bunch compost alone. The treatment of 80 $\mathrm{t}$ coal fly ash ha ${ }^{-1}$ combined with $20 \mathrm{t}$ oil palm empty fruit bunch compost ha ${ }^{-1}$ resulted in an increase in the P uptake by $303.23 \%$, dry weight of biomass by $329.59 \%$, and dry weight of seeds by $1,591.70 \%$ compared to control. The combination of $80 \mathrm{t}$ coal fly ash ha ${ }^{-1}$ with $20 \mathrm{t}$ oil palm empty fruit bunch compost ha-1 produced the highest $\mathrm{P}$ uptake, plant growth and yield, but they were not significantly different from those produced by the combination of $80 \mathrm{t}$ coal fly ash ha ${ }^{-1}$ with $20 \mathrm{t}$ oil palm empty fruit bunch compost $\mathrm{ha}^{-1}$ treatment. Therefore, when it is associated with the efficiency of input use (coal fly ash and oil palm empty fruit bunch compost), it is recommended to use a combination of $80 \mathrm{t}$ coal fly ash ha ${ }^{-1}$ with $20 \mathrm{t}$ oil palm empty fruit bunch compost $\mathrm{ha}^{-1}$ in the cultivation of maize on Ultisol of East Kalimantan.

Table 5. Effect of coal fly ash and oil palm empty fruit bunch compost on dry weights of cob with husks, cob with husks, roots, stems, leaves, and seeds of maize plant

\begin{tabular}{|c|c|c|c|c|c|c|c|c|c|c|c|c|}
\hline \multirow{3}{*}{$\frac{\text { Treatments }}{\text { AOKO }}$} & \multicolumn{12}{|c|}{ Dry weight $\left(\mathrm{g} \mathrm{pot}^{-1}\right)$} \\
\hline & \multicolumn{2}{|c|}{ Cob with husks } & \multicolumn{2}{|c|}{ Roots } & \multicolumn{2}{|c|}{ Stem } & \multicolumn{2}{|c|}{ Leaves } & \multicolumn{2}{|c|}{ Seeds } & \multicolumn{2}{|c|}{ Total biomass } \\
\hline & 18.92 & $f$ & 6.23 & c & 12.43 & $f$ & 14.95 & $\mathrm{~h}$ & 2.53 & $f$ & 55.06 & $\mathrm{~h}$ \\
\hline A20K0 & 32.78 & e & 15.37 & b & 36.07 & de & 40.40 & $f$ & 23.89 & d & 148.51 & $f$ \\
\hline A40K0 & 43.65 & $\mathrm{~cd}$ & 16.30 & $a b$ & 46.50 & $\mathrm{bc}$ & 45.37 & $\mathrm{e}$ & 33.84 & c & 185.66 & de \\
\hline A80K0 & 50.55 & $\mathrm{~b}$ & 16.47 & $a b$ & 50.23 & $\mathrm{~b}$ & 46.13 & $\mathrm{e}$ & 36.52 & $\mathrm{bc}$ & 199.90 & $\mathrm{~cd}$ \\
\hline A0K10 & 23.15 & $f$ & 15.40 & $\mathrm{~b}$ & 29.87 & $\mathrm{e}$ & 35.53 & $\mathrm{~g}$ & 14.40 & $\mathrm{e}$ & 118.35 & $\mathrm{~g}$ \\
\hline A0K20 & 41.21 & $\mathrm{~d}$ & 16.80 & $a b$ & 40.43 & $\mathrm{~cd}$ & 40.77 & $f$ & 28.70 & $d$ & 167.91 & $\mathrm{e}$ \\
\hline $\mathrm{A} 20 \mathrm{~K} 10$ & 42.36 & $\mathrm{~d}$ & 17.83 & $a b$ & 49.70 & $\mathrm{~b}$ & 46.50 & de & 34.93 & $\mathrm{bc}$ & 191.32 & $\mathrm{~cd}$ \\
\hline A20K20 & 47.84 & $\mathrm{bc}$ & 18.17 & $a b$ & 53.73 & $a b$ & 51.03 & $\mathrm{~cd}$ & 37.88 & $a b c$ & 208.65 & $\mathrm{bc}$ \\
\hline $\mathrm{A} 40 \mathrm{~K} 10$ & 48.42 & $\mathrm{bc}$ & 17.90 & $a b$ & 54.53 & $a b$ & 51.23 & $\mathrm{bcd}$ & 38.79 & $a b c$ & 210.87 & $\mathrm{bc}$ \\
\hline A40K20 & 50.76 & $b$ & 18.20 & $a b$ & 60.47 & $a$ & 55.07 & $a b c$ & 40.03 & $a b$ & 224.53 & $a b$ \\
\hline A80K10 & 55.96 & $\mathrm{a}$ & 19.43 & $\mathrm{a}$ & 60.53 & $a$ & 56.02 & $a b$ & 40.26 & $a b$ & 232.20 & $a$ \\
\hline A80K20 & 56.55 & $a$ & 19.58 & $a$ & 60.77 & $a$ & 56.83 & $a$ & 42.80 & a & 236.53 & $a$ \\
\hline
\end{tabular}

Remarks: $A=$ coal fly ash; $K=$ oil palm empty fruit bunch compost; $0,10,20.40$ and $80=$ Doses of coal fly ash or oil palm empty fruit bunch compost. Numbers followed by the same letter in the same column are not significantly different at $\alpha 5 \%$ DMRT. 


\section{Acknowledgements}

The authors wish to thank the Directorate of Research and Community Service, Ministry of Research, Technology and Higher Education of the Republic of Indonesia for funding this study. Thanks are also due to the Management and Staff of PT. Cahaya Fajar of East Kalimantan for providing coal fly ash, and PT. Surya Inti Sawit Kahuripan of Central Kalimantan for providing oil palm empty fruit bunch compost.

\section{REFERENCES}

1. Aggarwal, S., Singk, G.R., Yadav, B.R. 2009. Utilization of fly ash for crop production: effect on the growth of wheat and sorghum crops and soil properties. Journal of Agricultural Physics, 9, 20-23.

2. Ashish, T. 2017. Response of pea crop in fly ash amended soil. Annals of Horticulture, 10(1), 25-30. https://doi.org/10.5958/0976-4623.2017.00005.6

3. ASTM (American Society for Testing and Materials). 1988. Annual Book of ASTM Standards. Section 4: Construction. Vol.01.01: Cement, Lime, Gypsum

4. Bakar, R.A., Razak, Z.A., Ahmad, S.H., Seh-Bardan, B.J., Tsong, L.C., Meng, C.P. 2015. Influence of oil palm empty fruit bunch biochar on floodwater pHand yieldcomponents of rice cultivated on acid sulphate soilunder Rice Intensification Practices. Plant Production Science, 18(4), 491-500, https://doi.org/10.1626/pps.18.491.

5. Balemi, T., Negisho, K. 2012. Management of soil phosphorus and plant adaptation mechanisms to phosphorus stress for sustainable crop production: a review. Journal of Soil Science and Plant Nutrition, 12(3), 547-562, https://doi.org/10.4067/ S0718-95162012005000015.

6. Bharti, B., Matte, D.B., Badole, W.P., Deshmukh, A. 2000. Effect of fly ash on yield, uptake of nutrients and quality of green gram grown on a Vertisol. Journal of Soils and Crops, 10, 122-124.

7. Budianta, D., Wiralaga, A.Y.A., Wahana, L. 2010. Changes in some soil chemical properties of Ultisol applied by mulch from empty fruit bunches in an oil palm plantation. Journal of Tropical Soils, 15 (2), 111-118, https://doi.org/10.5400/ jts.2010.15.2.111.

8. Chaves, L.H.G., Estrela, M.A., de Souza, R.S. 2011. Effect on plant growth and heavy metal accumulation by sunflower. Journal of Phytology, 3(12), 4-9.

9. Ekpo, F.E., Okey, E.N., Asuquo, M.E. (2014). Effect of oil palm empty fruit bunches amendments in crude oil polluted soil on germination and growth performance of white mangrove species (Laguncularia racemosa). European Environmental Sciences and Ecology Journal, 1(1): 19-28.

10. Ermadani, M., Muzar, A. 2011. Effect of oil palm mill effluent application on soybean yield and changes in soil chemical properties of Ultisol. Indonesian Journal of Agronomy, 39(3), 160-167, http://dx.doi.org/10.24831/jai.v39i3.14959 (in Indonesian).

11. Fahrunsyah, Kusuma, Z., Prasetya, B., Handayanto, E. 2018. Improvement of some chemical properties of an Ultisol of East Kalimantan through an application of combined coal fly ash and oil palm empty fruit bunch. Bioscience Research, 15(3), 1805-1814.

12. Haynes, R.J., Mokolobate, M.S. 2001. Amelioration of al toxicity and deficiency in acid soil by additions of organic residues: A critical review of the phenomenon and the mechanisms involved. Nutrient Cycling in Agroecosystems, 59(1), 47-63.

13. Hermawan, A., Sabaruddin, M., Hayati, R., Warsito. 2014. Conversion of P adsorption on an Ultisol due to the mixture of fly ash of coal-chicken manure. Sains-Tanah: Journal of Soil Science and Agroclimatology, 11(1), 1-10, http://dx.doi. org/10.15608\%2Fstjssa.v11i1.198 (in Indonesian).

14. Hilman, Y., Rahim, A.B., Musaand, M.H., Hashim, A. 2007. Principal component analysis of factors determining phosphate rock dissolution on acid soils. Indonesian Journal of Agriculture Science, 8 (1), 10-16.

15. Ichriani, G.I., Syehfani, Nuraini, Y., Handayanto, E. 2017. Solubilization of inorganic phosphate by phosphate solubilizing fungi isolated from oil palm empty fruit bunches of Central Kalimantan. Bioscience Research, 14(3), 705-712.

16. Ichriani, G.I., Syehfani, Nuraini, Y., Handayanto, E. 2018. Formulation of biochar-compost and phosphate solubilizing fungi from oil palm empty fruit bunch to improve growth of maize in an Ultisol of Central Kalimantan. Journal of Ecological Engineering, 19(6), 45-55,https://doi. org/10.12911/22998993/92891

17. Ifansyah, H. 2013. Soil pH and solubility of aluminium, iron, phosphorus in ultisols: The role of humic acid. Journal of Tropical Soils, 18(3), 203208, https://doi.org/10.5400/jts.2013.18.3.203.

18. Ismail, M.R., Saud H.M., Habib, S.H., Hossain, K., Maleque, M.A., Hakim, M.A. 2017. Efficacy evaluation of oil palm empty fruit bunch compost in improving soil characteristics, plant growth and disease suppression of tomato plants under tropical acid soil. Journal of Environmental Biology, 38(1), 123-129, https://doi.org/10.22438/jeb/38/1/ PRN-126. 
19. Kishor, P., Ghosh, A.K., Kumar, D. 2010. Use of fly ash in agriculture: a way to improve soil fertility. Journal of Agricultural Research, 4(1), 1-14, https://doi.org/10.3923/ajar.2010.1.14

20. Kurniawan, A.R., Adenan, D.D., Untung, S.R., Hadijah, N.R., Alimana, M. 2010. Report on Research on Utilization of Coal Fly Ash of Steam Power Plant on Pre Reclamation of Coal Mine. Centre for Research and Development of Minerals and Coal Technology, Research and Development Agency of Energy and Mineral Resources (in Indonesian).

21. Lee, H., Ha, H.S., Lee, C.H., Lee, Y.B., Kim, P.J. 2006. Fly ash effect on improving soil properties and rice productivity in Korean paddy soils. Bioresource Technology, 97, 1490-1497.

22. Mahale, N.K., Patil, S.D., Sarodeand, D.B., Attarde, S.B. 2012. Effect of fly ash as an admixture in agriculture and the study of heavy metal accumulation in wheat (Triticum aestivum), mung bean (Vigna radiata) and urad beans (Vigna mungo). Polish Journal of Environmental Study, 221(6), 1713-1719.

23. Mengel, K., Kirkby, E.A., Kosegarten, H., Appel, T. 2001. Principles of Plant Nutrition. $5^{\text {th }}$ Edition, Kluwer Academic Publisher. London

24. Minardi, S., Harieni, S., Anasrullah, A., Purwanto, H. 2017. Soil fertility status, nutrient uptake, and maize (Zea mays L.) yield following organic matters and $\mathrm{P}$ fertilizer application on Andisols. IOP Conference Series: Materials Science and Engineering 193 (2017), https://doi.org/10.1088/1757899X/193/1/012054.

25. Mohammed, M.A.A., Salmiaton, A., Wan Azlina, W.A.K.G., Mohamad Amran, M.S. 2012. Gasification of oil palm empty fruit bunches: a characterization and kinetic study. Bioresource Technology, 110, 628-636, https://doi.org/10.1016/j. biortech.2012.01.056.

26. Muduli, S.D., Chaturvedi, N., Mohapatra, P., Dhal, N.K., Nayak, B.D. 2014. Growth and physiological activities of selected leguminous crops grown in carbonated fly ash amended soil. Greener Journal of Agricultural Sciences, 4 (3), 83-90, http:// dx.doi.org/10.15580/GJAS.2014.3.021114104

27. Panda, S.S., Mishra, L.P., Muduli, S.D., Nayak, B.D., Dhal, N.K. 2015. The effect of fly ash on vegetative growth and photosynthetic pigment concentrations of rice and maize. Biologija, 61(2): 94100, https://doi.org/10.6001/biologija.v61i2.3143.

28. Pathan, S.M, Aylmore, L.A.G., Colmer, T.D. 2003. Soil properties and turf growth on a sandy soil amended with fly ash. Plant and Soil, 256, 103-114.

29. Reddy, T.P., Umadevi, M., Rao, P.C. 2010. Effect of fly ash and farmyard manure on soil properties and yield of rice grown on an Inceptisol. Agricultural Science Digest, 30(4), 281-285.

30. Sharma, S.K., Kalra, N.2006. Effect of fly ash incorporation on soil properties and productivity of crops: A review. Journal of Scientific and Industrial Research, 65, 383-390.

31. Shen, J., Yuan, L., Zhang, J., Li, H., Bai, Z., Chen, X., Zhang, W., Zhang, F. 2011. Phosphorus dynamics: from soil to plant. Plant Physiology, 156, 997-1005, https://doi.org/10.1104/pp.111.175232.

32. Shenoy, V.V., Kalagudi, G.M. 2005. Enhancing plant phosphorus use efficiency for sustainable cropping. Biotechnology Advances, 23, 501-513.

33. Singh, R., Singh, D.P., Kumar, N., Bhargav, S.K., Barman, S.C. 2010. Accumulation of translocation of heavy metals in soil and plants from fly ash contaminated area. Journal of Environmental Biology, 31, 421-430.

34. Soil Research Institute of Indonesia. 2005. Technical Guidelines for Chemical Analyses of Soil, Plant, Water, and Fertilizer. Ministry of Agriculture of the Republic of Indonesia (in Indonesian).

35. Spark, K.M., Swift, R.S. 2008. Use of alkaline fly ash based productsto amend soils: extractability of selected elements and their uptakeby plants. Australian Journal of Soil Research, 46(7), 585- 599.

36. Sudaryono. 2009. Soil fertility rate of Ultisol at Sangatta coal field, East Kalimantan. Jurnal Teknologi Lingkungan-BPPT, 10(3), 337-346 (in Indonesian).

37. Thao, H.T.B., George, T., Yamakawa, T., Widowati L.R. 2008. Effects of soil aggregate size on phosphorus extractability and uptake by rice (Oryza sativa L.) and corn (Zea mays L.) in two Ultisols from the Philippines. Soil Science and Plant Nutrition, 54, 148-158, https://doi.org/10.1111/j.17470765.2007.00220.x.

38. Udoetok, I.A. 2012. Characterization of ash made from oil palm empty fruit bunches. International Journal of Environmental Sciences, 3(1), 518-524, https://doi.org/10.6088/ijes.2012030131033.

39. Ukwattage, N.L., Gamage, R.P., Bouazza, A. 2013. Theuse of coal combustion fly ash as a soil amendment in agricultural lands (with comments on its potential to improve food security and sequester carbon). Fuel, 109, 400-408, https://doi. org/10.1016/j.fuel.2013.02.016. 